\title{
P
}

\section{Characterization of weed flora in rubber trees plantations of Bongo (Côte d'Ivoire)}

TUO Korna F. André1, OREGA Youppo Barthélémy², KOUAME Koffi Badou Jérémie², ABO Kouabenan², AGNEROH Thérèse Atcham²

1 Institut National Polytechnique Félix Houphouët-Boigny, École Supérieure d'Agronomie

2 Institut National Polytechnique Félix Houphouët-Boigny, Département de Formation de Recherche Agriculture et Ressources Animales

BP 1313 Yamoussoukro

* Corresponding author. E-mail:ie.badou@yahoo.fr Tél: +225 49999462

Original submitted in on 30th May 2013 Published online at www.m.elewa.org on 31 $1^{\text {st }}$ October 2013.

https://dx.doi.org/10.4314/jab.v70i1.98753

\section{ABSTRACT:}

Objectives: the main objective of this study is to characterize the weed floristic diversity of the Bongo rubber trees plantation and to provide a map for sustainable weed management

Methodology and results: a floristic survey of the Para rubber plantations of Bongo (Southeast Côte d'Ivoire) was conducted in 2007 and early 2008. The field tour method was used for weed inventory in 27 plots of 25 ha of different ages. Moreover, the coverage rate of weeds was estimated in samples of 100 square meters each for every plot. Weeds flora is composed of 168 species scattered in the entire rubber trees plantation. These species were distributed in 63 families and 140 genera. The eleven most representative botanical families, constituting more than the half of the flora (50\% of the species), are Rubiaceae, Apocynaceae, Poaceae, Cyperaceae, Euphorbiaceae, Moraceae, Amaranthaceae, Mimosaceae, Fabaceae, Cucurbitaceae and Commelinaceae. Weeds' mapping was established and illustrated by 4 main weed groups in relation with the stage of rubber trees development. For the plantations of 1 and 2 years old, weeds were dominated by leguminous cover crop Pueraria phaseoloides (Roxb.) Benth. Weed species really begin to establish in the plantation from 8 to 12 years old with appearance of species such as Palisota hirsuta (Thumb.) Engl. and Aneilema beniniense Kunth. Fields of 13 to 23 years old are covered at about $83.5 \%$ by Palisota hirsuta (Thumb.) Engl.

Conclusion and application of results: The weed mapping will assist in weed management

Key words: weeds, floristic study, planting year, mapping

\section{INTRODUCTION}

In 2004, the African production of latex was 474,000 tons and represented $5 \%$ of the world production (CNRA, 2006). According to the same author, the yearly production of Côte d'Ivoire in 2004 was estimated to 136,000 tons which placed the rubber production as one of the main cash crops of the country. In 2005, Côte d'lvoire produced 165,000 tons and was the first producer of natural rubber in Africa and the seventh worldwide (APROMAC, 2005). Many constraints are limiting this production and lead to yield losses in the plantations among which are weeds. They are harmful to rubber tree growth as they contend with rubber for light, moisture and nutrients, especially during the initial years of a plantation (RBI, 2005). In Southeast Asia for example, the grass Imperata cylindrica, competes vigorously with rubber for moisture and nutrients and in the early phases of rubber tree development it can diminish the growth of the tree by up to $50 \%$ (Grist 
et al., 1998). Yields from the cropping areas infested by Imperata can be decreased by up to 90\% (Menz and Grist, 1995). Additionally, in mature rubber the presence of weeds can be a factor of yield losses: discomfort for the tapper to move and bad monitoring of the tapping process. Weeds can also enhance the expansion of bushfires which are factors of plantation destruction. There is a need to achieve a sustainable management of weeds in Ivorian rubber plantations. But, one of the main constraints to the use of improved control methods of weeds is their identification (Merlier and Montegut, 1982). Knowing the composition of the weed flora and its evolution under the impact of environmental and

\section{MATERIAL AND METHODS}

Experimental site : The Agricultural Integrated Unit (AIU) of Bongo $\left(5^{\circ} 28^{\prime \prime} \mathrm{N}\right.$ and $\left.3^{\circ} 35^{\prime \prime} \mathrm{O}\right)$ is located in the District of Bonoua, in the south-east of Côte d'Ivoire. It covers around 7,012 ha with an industrial farm of rubber of 5,500 ha. This AIU is located at $50 \mathrm{Km}$ of Bonoua. It is completely located in the Guinean geographical zone. There are typically four seasonal variations: a long dry period (December to March), a long rainy season (March to June), a minor dry season (July to August) and finally a minor rainy season (September to November). Annual rainfall generally exceeds $1,500 \mathrm{~mm}$. More specifically, the average of annual rainfall of the AIU of Bongo is $1,670 \mathrm{~mm}$ (AIU meteorological station). For the year 2007 the AIU received a total rainfall of $2,127 \mathrm{~mm}$; the months with the highest rainfall were May $(224 \mathrm{~mm})$, June (254 $\mathrm{mm})$, July $(271 \mathrm{~mm})$ and October $(314 \mathrm{~mm})$. The annual temperatures range between 26 and $27^{\circ} \mathrm{C}$. The monthly sunshine duration ranges between 80 and 220 hours with an annual average of 1,700 hours. The soils of the District of Bonoua are generally ferralitic more or less desaturated, and sandy-clay.

Material and methods : Floristic studies were carried out to identify all the weeds of the different plots of the farm and to present their distribution at the scale of the whole farm. The total area of the plantation is $5,500 \mathrm{ha}$. The sampling for identification of weeds of the farm permitted to take into account the plots of different ages on the AIU. Consequently, a total number of 27 plots were chosen (Table 1). The field tour method was used for the survey. It is a flora survey technique which allows inventorying exhaustively the different species of the field (Chicouene, 2000; Kouame et al., 2011). It consists in going through the field in many directions to find any new species. The discovery of a new species leads to a thorough exploration (Lebreton and Le phytotechnic factors is a basic prerequisite for any improvement of control methods (Lebreton and Le Bourgeois, 2005). Therefore, the first challenge to those faced with a weed control problem is, usually, to identify the weed species involved. Without this first step, it is hard to have confidence in one's efforts (Johnson, 1997). The objectives of this study were to (i) characterize the weed floristic diversity of the plantation, (2) analyze the evolution of the coverage of the main weeds on the Bongo plantation as rubber trees are growing, and (3) provide a map of the floristic groups for future research activities on sustainable and precise weed management methods suitable for each group.

Bourgeois, 2005). This method has the advantage to take into account the heterogeneity of the field to the extent that it does not show a main ecological and floristic difference (Kouame et al., 2011; Chicouene, 1999). The determination of the species encountered was realized in two steps. Firstly, the identification tools of Berhaut (1967), Hutchinson and Dalziel (1954), Johnson (1997), and of Merlier and Montegut (1982) were used. Secondly, the remaining species were identified at the National Center of Floristic of the University Houphouet-Boigny of Cocody (Abidjan) with the help of an expert in systematic. A second method, was used to study the coverage of the various weeds. It was carried out in all the plots of the same age and was used for mapping weeds of the whole farm. In each plot of 25 ha, five sites of $100 \mathrm{~m}^{2}$ each were randomly sampled for data collection. The inventory of the weed flora was followed by the attribution of a number of coverage ranging between 1 and 9 according to the scale of "Commission des Essais Biologiques (CEB)"revised by Marnotte (2000) as indicated in the Table 2. The use of a Geographical Positioning System (GPS) receptor Garmin made easier the positioning in the plantations during the investigation and the georeferencing of the plots. 
Tuo et al. J. Appl. Biosci. 2013. Characterization of weed flora in rubber tree plantations of Bongo (Cote d'Ivoire)

Table 1: Plots of weeds identification

\begin{tabular}{|c|c|}
\hline Plots number & Age (years) \\
\hline E14 & 36 \\
\hline D15 & 34 \\
\hline A 12 & 33 \\
\hline A9 & 32 \\
\hline E 7 & 31 \\
\hline J8 & 30 \\
\hline R 13 & 29 \\
\hline R 11 & 28 \\
\hline N9 & 27 \\
\hline K 4-5 & 26 \\
\hline P9 & 23 \\
\hline H 6-7 & 22 \\
\hline F 11 & 20 \\
\hline Q 22 & 19 \\
\hline K 12 & 18 \\
\hline R 16 & 17 \\
\hline Q 16 & 16 \\
\hline P 15 & 15 \\
\hline N7 & 14 \\
\hline P 16 & 13 \\
\hline M 17 & 12 \\
\hline J 15 & 11 \\
\hline H 15 & 10 \\
\hline H 18 & 9 \\
\hline F 17 & 8 \\
\hline G 11 & 2 \\
\hline J13 & 1 \\
\hline
\end{tabular}

The plots can be found on the map of the plantations with alphanumeric numeration

Table 2: Rating scale for weeds coverage (Marnotte, 2000)

\begin{tabular}{ccl}
\hline Scale & Percentage $(\%)$ & Coverage \\
\hline $\mathbf{1}$ & 1 & Species are present, but rare \\
$\mathbf{2}$ & 7 & Less than one individual per square meter \\
$\mathbf{3}$ & 15 & At least one individual per square meter \\
$\mathbf{4}$ & 30 & $30 \%$ of coverage \\
$\mathbf{5}$ & 50 & $50 \%$ of coverage \\
$\mathbf{6}$ & 70 & $70 \%$ of coverage \\
$\mathbf{7}$ & 85 & High coverage \\
$\mathbf{8}$ & 93 & Only a small soil surface visible \\
$\mathbf{9}$ & 100 & Total coverage \\
\hline
\end{tabular}

Analysis of data : Two parameters determined via the data of inventory were selected for the analysis of the results. These parameters are floristic diversity and rate of coverage of the species. The data for weeds mapping were analyzed with the Geographical Information System (GIS) software ArcGIS 9.2. 


\section{RESULTS}

The results reveal the characteristics of the weed flora in the plots of the AlU of Bongo. These characteristics are floristic diversity and soil coverage rate.

Floristic diversity of the Agricultural Integrated Unit : The results of the study of the weed flora of the plantations are listed in the Tables 3 and 4 . A total of 168 species were collected and identified on the different plots (Table 4). These species were distributed in 63 families and 140 genera (Table 3 and 4). The 11 most representative botanical families, constituting more than $50 \%$ of the identified species, are Rubiaceae (12 species), Apocynaceae (12 species), Poaceae (11 species), Cyperaceae (9 species), Euphorbiaceae (7 species), Moraceae (7 species), Amaranthaceae ( 6 species), Mimosaceae (6 species), Fabaceae ( 5 species), Cucurbitaceae (5 species) and Commelinaceae (4 species). The number of genera per family ranges between 1 and 12 . However, there are few species per genus (only 1 species) in majority. Only few genera such as Cyperus (6 species), Ficus (4 species), Clerodendron, Spermacoce (3 species) are largely represented.

Soil coverage and weed species mapping : The results of the analyzed inventory are presented in the
Table 3. The composition of the weed flora is not in majority floristically and ecologically different from one plot to another for the plantations of the same age. Generally, the plots of the farm are mainly infested by Palisota hirsuta (Thumb.) Engl. For the 10 mature rubber plots ( $\left.E_{14}, D_{15}, A_{12}, A_{9}, E_{7}, J_{8}, R_{13}, R_{11}, N_{9}, K_{4-5}\right)$ of 26 to 36 years old, the same weed flora was encountered no matter the planting year. Some species were distributed in all the plots of the farm. They are namely, Commelinaceae species such as: Palisota hirsuta (Thumb.) Engl. (coverage frequencies can exceed 83\%), Stanfieldiella imperforata (C. B. Cl.) Brenan (with a maximum coverage of $50 \%$ ), Aneilema beniniense Kunth. (with a maximum coverage of $50 \%)$. The coverage frequencies and vegetative aspect of the weeds in plots permitted to make a major floristic difference and classify the plots of the AIU into four major groups.

These groups are essentially four classes of age determined in relation to the rate of coverage of the soil surface by the canopy of the rubber trees. Each floristic group (class of age) is characterized by the percentage of coverage of its constituting species. 
Tuo et al. J. Appl. Biosci. 2013. Characterization of weed flora in rubber tree plantations of Bongo (Cote d'lvoire)

Table 3: Classification of the species per family

\begin{tabular}{|l|c|c|}
\hline Families & species & $\%$ \\
\hline Acanthaceae & 1 & 0.60 \\
\hline Adiantaceae & 3 & 1.79 \\
\hline Agavaceae & 1 & 0.60 \\
\hline Amaranthaceae & 6 & 3.57 \\
\hline Amaryllidaceae & 2 & 1.19 \\
\hline Apocynaceae & 12 & 7.14 \\
\hline Araceae & 3 & 1.79 \\
\hline Asclepiadaceae & 3 & 1.79 \\
\hline Aspidiaceae & 1 & 0.60 \\
\hline Asteraceae & 3 & 1.79 \\
\hline Barringtoniaceae & 1 & 0.60 \\
\hline Bombacaceae & 1 & 0.60 \\
\hline Caesalpiniaceae & 2 & 1.19 \\
\hline Capparidaceae & 1 & 0.60 \\
\hline Chrysobalanaceae & 1 & 0.60 \\
\hline Commelinaceae & 4 & 2.38 \\
\hline Connaraceae & 2 & 1.19 \\
\hline Convolvulaceae & 1 & 0.60 \\
\hline Cucurbitaceae & 5 & 2.98 \\
\hline Cyperaceae & 9 & 5.36 \\
\hline Davalliaceae & 1 & 0.60 \\
\hline Dennstaedtiaceae & 1 & 0.60 \\
\hline Dioscoreaceae & 2 & 1.19 \\
\hline
\end{tabular}

\begin{tabular}{|l|c|c|}
\hline Families & Species & $\%$ \\
\hline Dracaenaceae & 1 & 0.60 \\
\hline Euphorbiaceae & 7 & 4.17 \\
\hline Fabaceae & 8 & 4.31 \\
\hline Flacourtiaceae & 2 & 1.19 \\
\hline Flagellariaceae & 1 & 0.60 \\
\hline Hippocrateaceae & 1 & 0.60 \\
\hline Lamiaceae & 2 & 1.19 \\
\hline Mimosaceae & 6 & 3.24 \\
\hline Loganiaceae & 1 & 0.60 \\
\hline Malpighiaceae & 2 & 1.19 \\
\hline Malvaceae & 1 & 0.60 \\
\hline Marantaceae & 2 & 1.19 \\
\hline Melastomataceae & 2 & 1.19 \\
\hline Meliaceae & 2 & 1.19 \\
\hline Melianthaceae & 1 & 0.60 \\
\hline Menispermaceae & 3 & 1.79 \\
\hline Moraceae & 7 & 4.17 \\
\hline Nearantaceae & 1 & 0.60 \\
\hline Olacaceae & 2 & 1.19 \\
\hline Onagraceae & 1 & 0.60 \\
\hline Papilionaceae & 1 & 0.60 \\
\hline Passifloraceae & 2 & 1.19 \\
\hline Pandaceae & 1 & 0.60 \\
\hline
\end{tabular}

\begin{tabular}{|l|c|c|}
\hline Families & Species & $\%$ \\
\hline Poaceae & 11 & 6.55 \\
\hline Polygalaceae & 1 & 0.60 \\
\hline Polypodiaceae & 1 & 0.60 \\
\hline Rhamnaceae & 1 & 0.60 \\
\hline Rubiaceae & 12 & 7.14 \\
\hline Salaginellaceae & 1 & 0.60 \\
\hline Sapindaceae & 1 & 0.60 \\
\hline Simaroubaceae & 1 & 0.60 \\
\hline Sterculiaceae & 1 & 0.60 \\
\hline Thelypteridaceae & 2 & 1.19 \\
\hline Tiliaceae & 2 & 1.19 \\
\hline Urticaceae & 3 & 1.79 \\
\hline Verbenaceae & 3 & 1.79 \\
\hline Violaceae & 1 & 0.60 \\
\hline Zingiberaceae & 2 & 1.19 \\
\hline
\end{tabular}


Tuo et al. J. Appl. Biosci. 2013. Characterization of weed flora in rubber tree plantations of Bongo (Cote d'Ivoire)

Table 4: Species' generic distribution

\begin{tabular}{|c|c|c|c|c|c|}
\hline Genera & Species & Genera & Species & Genera & Species \\
\hline Accacia & 1 & Cercestis & 1 & Flagellaria & 1 \\
\hline Acridocarpus & 1 & Chassalia & 1 & Fleurya & 1 \\
\hline Adenia & 2 & Chromolaena & 1 & Funtumia & 1 \\
\hline Adiantum & 1 & Chytrathus & 1 & Geophila & 1 \\
\hline Aframomum & 1 & Clerodendron & 3 & Glyphaea & 1 \\
\hline Ageratum & 1 & Cnestis & 1 & Gongronema & 1 \\
\hline Alafia & 2 & Coccina & 1 & Griffonia & 1 \\
\hline Albertisia & 1 & Cola & 1 & Halopegia & 1 \\
\hline Albizia & 2 & Combretodendron & 1 & Hannoa & 1 \\
\hline Alchornea & 1 & Commelina & 1 & Heisteria & 1 \\
\hline Alstonia & 1 & Costus & 1 & Homalium & 1 \\
\hline Alternanthera & 1 & Crinum & 2 & Hyppolytrum & 1 \\
\hline Amaranthus & 2 & Croton & 1 & Hypselodelphys & 1 \\
\hline Anchomanes & 1 & Ctenitis & 1 & Hyptis & 1 \\
\hline Aneilema & 1 & Cyathula & 1 & Justicia & 1 \\
\hline Angylocalyx & 1 & Cyclosorus & 2 & Landolphia & 1 \\
\hline Anthocleista & 1 & Cyperus & 6 & Leptoderris & 1 \\
\hline Antiaris & 1 & Digitaria & 1 & Ludwigia & 1 \\
\hline Axonopus & 1 & Dimorphochlamys & 1 & Macaranga & 1 \\
\hline Baissea & 1 & Dioscorea & 2 & Magnistipula & 1 \\
\hline Bambusa & 1 & Dissotis & 1 & Manotes & 1 \\
\hline Baphia & 1 & Dracaena & 1 & Mariscus & 2 \\
\hline Bersama & 1 & Eleusine & 1 & Massularia & 1 \\
\hline Calycobolus & 1 & Emilia & 1 & Megastachya & 1 \\
\hline Carpolobia & 1 & Eragrostis & 1 & Microdesmis & 1 \\
\hline Cecropia & 1 & Erythrococca & 1 & Mikania & 1 \\
\hline Ceiba & 1 & Euadenia & 1 & Milicia & 1 \\
\hline Celosia & 1 & Euphorbia & 1 & Millettia & 1 \\
\hline Centrosema & 1 & Ficus & 4 & Mimosa & 2 \\
\hline Momordica & 1 & Physedra & 1 & Rinorea & 1 \\
\hline Nephrolepis & 1 & Piptadeniastrum & 1 & Ruthalicia & 1 \\
\hline Olax & 1 & Pityrogramma & 1 & Sabicea & 2 \\
\hline Oldenlandia & 1 & Platostoma & 1 & Salacia & 1 \\
\hline Oncinotis & 2 & Pleioceras & 1 & Salaginella & 1 \\
\hline Oplismenus & 1 & Psychobria & 1 & Strophanthus & 1 \\
\hline Palisota & 1 & Psydrax & 1 & Synedrella & 1 \\
\hline Panicum & 2 & Pteridium & 1 & Sansevieria & 1 \\
\hline Paspalum & 1 & Pteris & 1 & Scottellia & 1 \\
\hline Pennisetum & 1 & Pueraria & 1 & Secamone & 1 \\
\hline Phyllanthus & 2 & Rauvolfia & 1 & Setaria & 1 \\
\hline Phymatodes & 1 & Rhigiocarya & 1 & Sherbournia & 1 \\
\hline Sida & 1 & Sphenocentrum & 1 & Stanfieldiella & 1 \\
\hline Spermacoce & 3 & Thaumatococcus & 1 & Stemonocoleus & 1 \\
\hline Triapsis & 1 & Tabernaemontana & 1 & Spermacoce & 3 \\
\hline Trichilia & 2 & Xanthomonas & 1 & Tristemma & 1 \\
\hline Triumfetta & 1 & Tylophora & 1 & Urera & 2 \\
\hline Ventilago & 1 & Vernonia & 1 & & \\
\hline
\end{tabular}


Table 4 illustrates the low average number of species per genus (1).

- First floristic group: For these immature rubber plantations of 1 and 2 years old, the leguminous cover crop Pueraria phaseoloides (Roxb.) Benth has more than a high coverage of soil surface $(95.45 \%)$.
Only small surfaces of soil are visible. Few weeds can appear in these plots: Cecropia peltata L., Aneilema beniniense Kunth., Thaumatococcus daniellii Benn. and Panicum maximum Jacq. (Figure 1). Among these species Panicum maximum Jacq has the highest coverage $(7 \%)$.

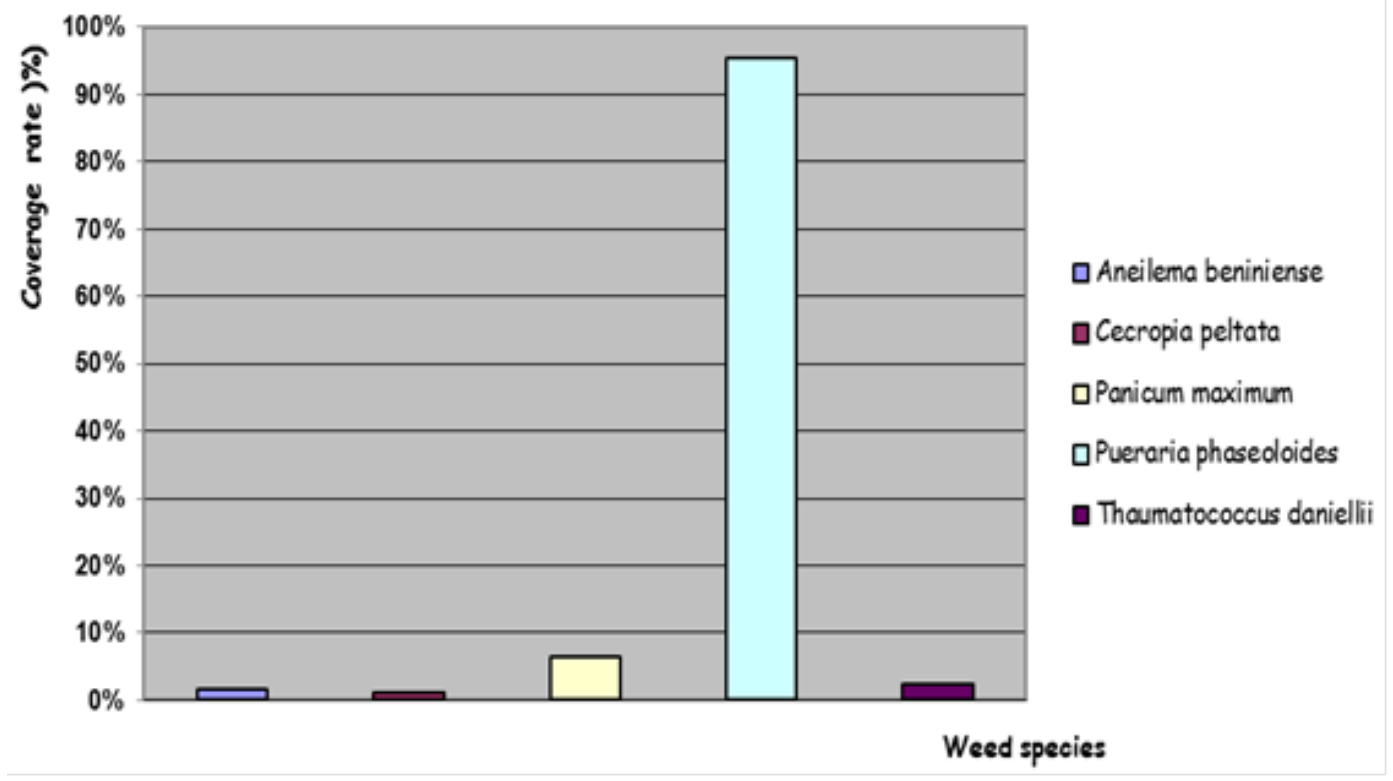

Figure 1: Weeds of the first floristic group

- Second floristic group: The plots of the second group have a more diversified weed flora. This floristic group is constituted of many species that have, however, low proportions (below $30 \%$ ). In this class of plots, rubber trees are 8 to 12 years old. Pueraria phaseoloides (Roxb.) Benth. disappears due to the development of the canopy of rubber trees; the soil surface is available for weeds infestation. From this vegetative step of the trees, weeds start to appear and cover the soil of the plots. The most competitive species emerge then and cover the soil surface space left free by Pueraria phaseoloides (Roxb.) Benth. Consequently, this growing stage is the starting point of higher infestations of Palisota hirsuta (Thumb.) Engl. The percentages of coverage of different species are illustrated by figure 2 . 


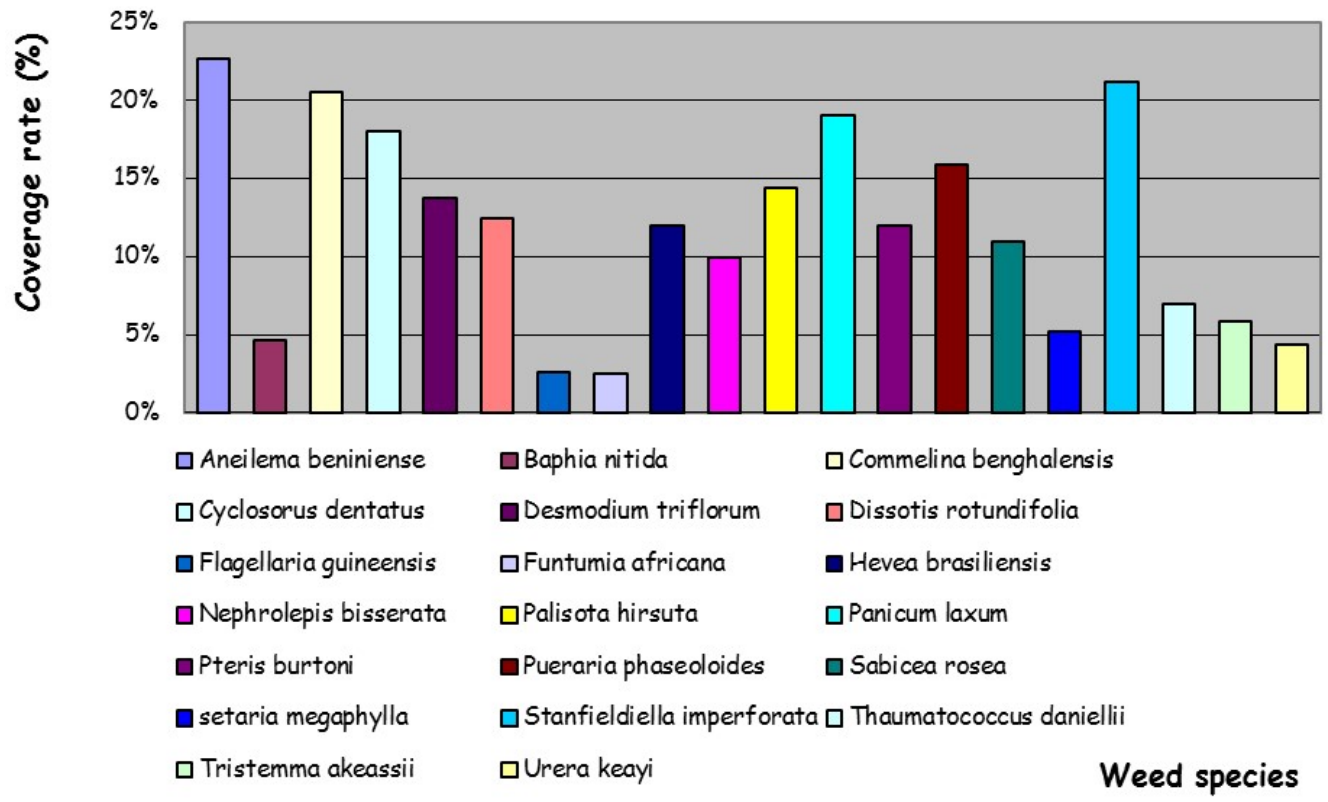

Figure 2: Weeds of the second floristic group

- $\quad$ Third floristic group: The most troublesome weed in the third floristic group is Palisota hirsuta (Thumb.) Engl. which covers all the plots ranging between 13 and 23 years old at $83.5 \%$ (Figure 3).However, other species, are well represented in the third group. These species are Aneilema beniniense
Kunth., Chassalia corallifera (A Chev.) Hepper, Stanfieldiella imperforata (C. B. Cl.) Brenan, Pteris burtoni Bak., Nephrolepis bisserata (Sw.) Schott and woody weeds such as Funtumia africana Benth. and Baphia nitida Lodd.

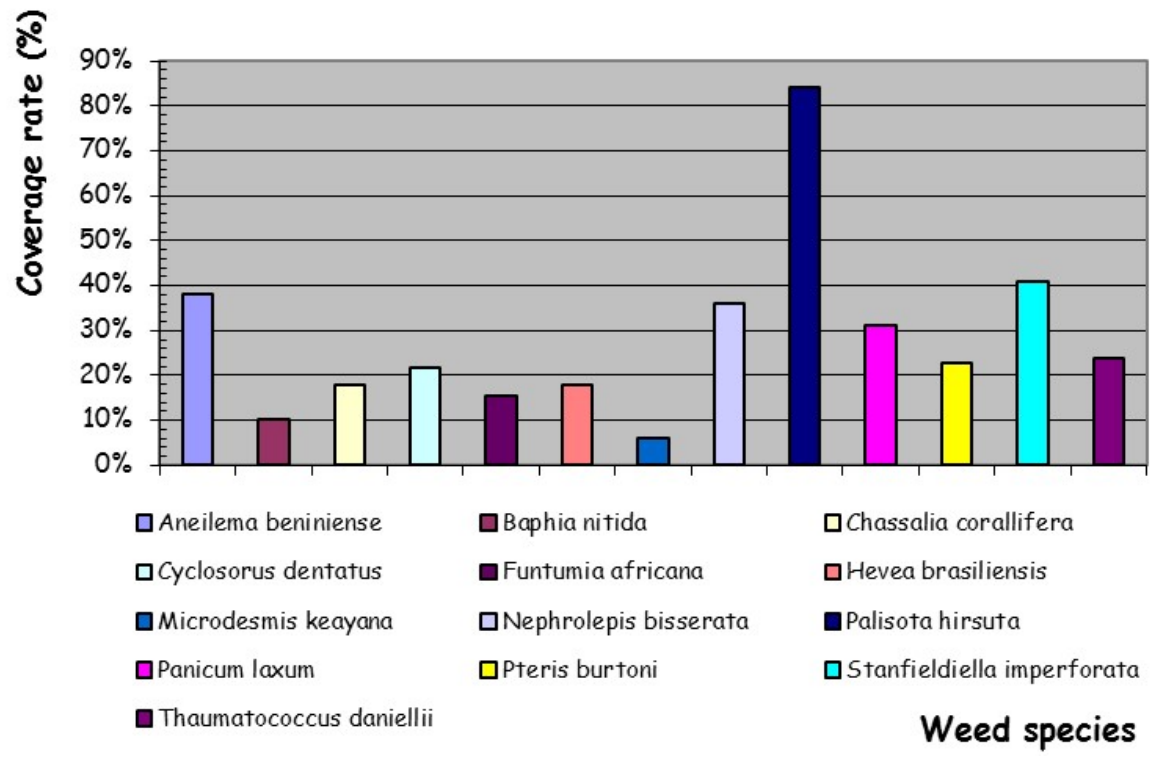

Figure 3: Weeds of the third floristic group

- $\quad$ Fourth floristic group: The fourth floristic group is, instead, characterized by weeds that are more developed, based on the vegetative aspect, than those of the other groups; they are mainly composed of woody weeds (Figure 4). The development of woody weeds such as Baphia nitida Lodd., Funtumia africana Benth. and Microdesmis keayana J. L. clearly visible. There is, also, a high development of natural rubber 
plants (germination ). Beside these woody weeds, many other species such as Nephrolepis bisserata (Sw.) Schott, Stanfieldiella imperforata (C. B. Cl.)
Brenan, Triapsis odorata (Willd.) A. Juss. and Aneilema beniniense Kunth. grow in this group with various coverage rates.

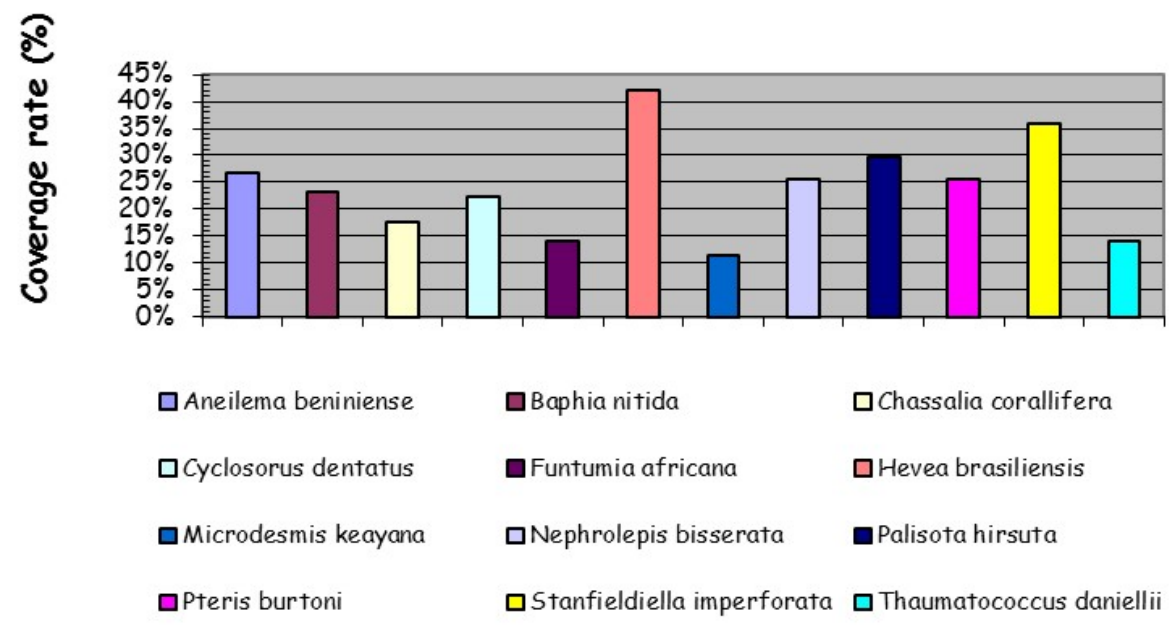

Weed species

Figure 4: Weeds of the fourth floristic group

Mapping the four floristic groups: The four groups of weeds are illustrated by the Figure 5 .

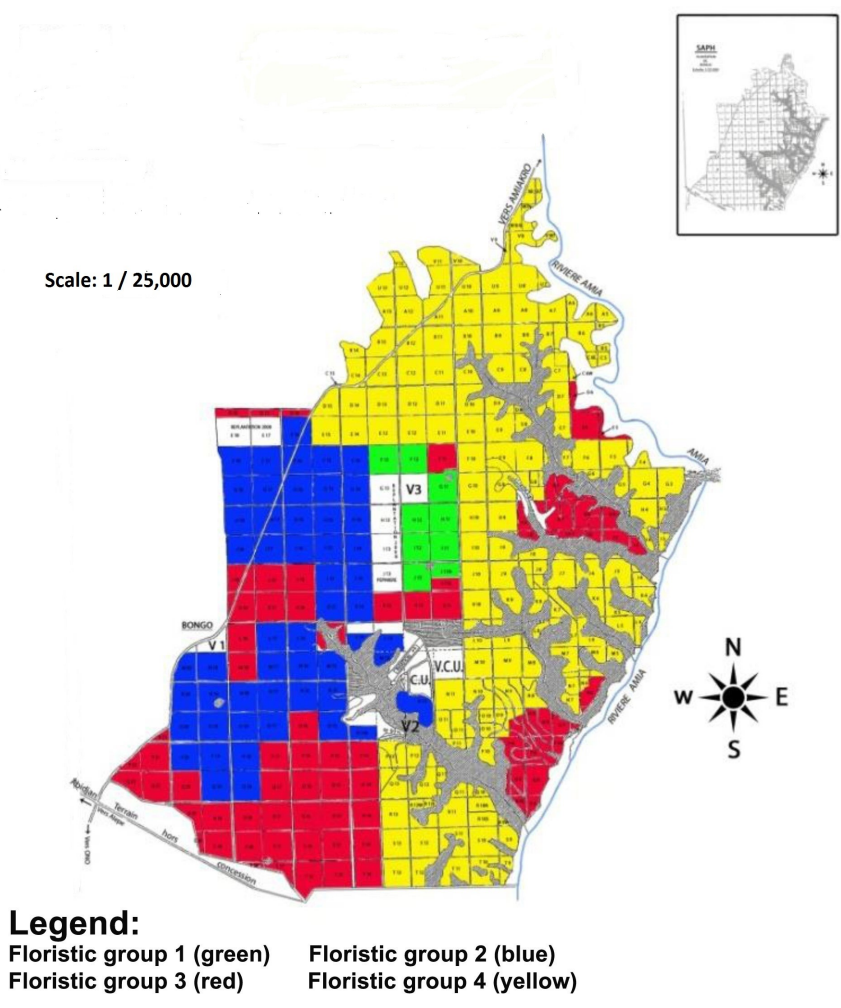

Figure 5: Map of the distribution of the four groups of weed in the AIU 
DISCUSSION

Floristic diversity : According to Akobundu (1987), 10 families comprise the most species considered as « major world weeds ».Those families are Euphorbiaceae, Malvaceae, Asteraceae, Poaceae, Cyperaceae, Convolvulaceae, Fabaceae, Polygonaceae, Amaranthaceae and Solanaceae. Among those 10 aforementioned families, 5 dominant families were found during our fieldwork at the Agricultural Integrated Unit of Bongo: Euphorbiaceae, Asteraceae, Poaceae, Cyperaceae, Convolvulaceae, Amaranthaceae, and Fabaceae. These results are closed to those of Le Bourgeois and Guillerm (1995), Aman et al., (2004), who noted the dominance of 5 families (Euphorbiaceae, Asteraceae, Poaceae, Cyperaceae, Rubiaceae) in the crops' weed flora. Generally, the floristic diversity of the AIU of Bongo shows a likeness with the Ivorian flora (Aké, 2002) characterized by 7 dominant families of Angiosperms that are Leguminoseae, Rubiaceae, Poaceae, Orchidaceae, Cyperaceae, Euphorbiaceae and Asteraceae.

Evolution of the structure and the diversity of weeds community: The distribution and the coverage rates of various weeds are linked to rubber trees canopy closure. According to Compagnon (1986), after planting and while the trees canopy is closing, the weed flora decreases and its composition changes towards shade-demanding species: ferns, woody, seedling of rubber. The mapping of the weeds of the plantation, taking into account the major weeds and their proportions, was illustrated by four weed floristic groups. Firstly, the immature rubber plots of 1 and 2 years old are covered at $95.45 \%$ by Pueraria

\section{CONCLUSION}

This floristic survey and the mapping of the weeds of the AIU of Bongo (African Society of Rubber Plantations (SAPH)) contribute to an in-depth analysis of the weeds distribution. The study mapped the weeds in relation to the development stage of the canopy of the rubber trees. One hundred and sixty eight (168) species of weeds were collected and identified on the different plots, distributed in 63 families and 140 genera. The 11 most representative botanical families, constituting more than $50 \%$ of the identified species

\section{ACKNOWLEDGEMENT}

The authors are very grateful to professor AKE-ASSI Laurent, botanist, systematic expert at the National Center of Floristic of Côte d'Ivoire, for his considerable

\section{REFERENCES}

Aké Assi L, 2002. Flore de la Côte d'Ivoire: catalogue systématique, biogéographie et écologie. phaseoloides (Roxb.) Benth. The cultivation of this leguminous cover crop is essential and important in maintaining the fertility of rubber growing soils. The advantages of cover crop include fixation of atmospheric nitrogen, prevention of soil erosion, suppression of weed growth (particularly the grasses which emerge spontaneously after forest clearing). However, few weeds have a successful emergence in this group: Cecropia peltata L., Aneilema beniniense Kunth., Thaumatococcus daniellii Benn. and Panicum maximum Jacq. This situation is due to the fact that, as the cover plant and weeds compete for the same limited resources, when the cover plant establishes early, before the emergence of weeds its canopy covers the soil surface and creates a microenvironment that is not suitable for germination, emergence and growing of weeds. Conversely, when the emergence of the cover plant is delayed, weeds emerge. Generally, the canopy of rubber trees increases and produces a continuous shade at $8-10$ years old, that allow the growth of shade-demanding species (Compagnon, 1986). The quantity and quality of the light captured by species growing under the rubber trees is variable. In relation with the age of the trees, an important part of light can reach the soil surface whenever the canopy is open. Conversely, when the canopy closes there is no more light at the soil surface which leads to the appearance of shade-demanding species. According to Fenner (1978), weeds are relatively sensible to negative effects of the shade. Similarly, the age of the rubber trees seems to increase the spontaneous woody species.

are Rubiaceae, Apocynaceae, Poaceae, Cyperaceae, Euphorbiaceae, Moraceae, Amaranthaceae, Mimosaceae, Fabaceae, Cucurbitaceae and Commelinaceae. The number of genera per family ranges between 1 and 12 . This species' inventory and mapping is useful and helpful for all the producers of rubber trees of this agroecological zone (Bonoua and Adiaké) while dealing with weed pressure and especially while choosing appropriate weed control methods.

support and assistance in the identification of numerous specimens.

Volume 1: Mémoire de Botanique systématique. Conservatoire et Jardin 
Botanique de Genève ; Boisseria 58 ; 441 pages.

Akobundu IO, 1987. "Weed science in the tropics. Principles and practices", Wiley, Chichester, UK. $522 \mathrm{p}$.

Aman Kadio G, Ipou Ipou J, Touré Y, 2004. La flore des adventices des cultures cotonnières de la région du Worodougou, au Nord-ouest de la Côte d'Ivoire", Agron. Afr. 16(1): 1-14.

APROMAC, 2005. Etat de la production de caoutchouc naturel en tonnage sec en Côte d'Ivoire. Revue de l'Association des Producteurs et Manufacturiers du Caoutchouc. P 25.

Berhaut J, 1967. Flore du Sénégal. France.Clair afrique, Dakar (Sénégal)

CNRA, 2006. Bien cultivar l'hévéa en Côte d'Ivoire. Fiche hévéa $n^{\circ} 1$. Centre National de Recherche Agronomique. $4 \mathrm{p}$.

Chicouene D, 2000. Evaluation du peuplement de mauvaises herbes en végétation dans une parcelle: II - Protocoles rapides pour un usage courant. Phytoma - Défense des cultures $524: 11 \mathrm{p}$.

Compagnon P, 1986. Le caoutchouc naturel. Série Techniques d'agriculture Tropicale ; Editions G.P. Maisonneuve and Larose. 595 p.

Fenner M, 1978. Susceptibility to shade in seedlings of colonizing and closed turf species. New Phytol. 81: 739-744.

Grist P, Menz K, and Thomas, 1998. 'Modified BEAM Rubber Agroforestry Models: RRYIELD and RRECON'. ACIAR Technical Reports Series No. 42. ACIAR: Canberra.

Hutchinson J, Dalziel JM, 1954.Flora of west tropical africa. Volume 1, Part 1. (Second edition revised by R. W. J. Keay). Crown Agents for Oversea Governments and Administrations, London, UK.

Johnson DE, 1997. Weeds of rice in West Africa. $311 p$.

Kouame KF, Ipou Ipou J, Toure A, N'Guessan KE, 2011.Major weeds of rice agro-ecosystems in Côte d'Ivoire. Agric. Biol. J. N. Am., 2 (9): 1317-1325.

Lebreton G, Le Bourgeois T, 2005. Analyse de la flore adventice de la lentille à cilaos-Réunion. CIRAD-Ca/3P UMR PVBMT. 19p.

Lebreton G, Le Bourgeois T, 2005. Analyse comparée de la flore adventice en culture d'ananas et de canne à sucre à la Réunion. CIRAD-CA/3PUMR PVBMT, 12.

Le Bourgeois T, Guillerm JL, 1995. Etendue de distribution et degrés d'infestation des adventices dans la rotation cotonnière du Nord-Cameroun", Weed Res. 35: 89-98.
Marnotte $P, 2000$. La gestion de l'enherbement et l'emploi des herbicides dans les systèmes de culture en zone Soudano-sahélienne en Afrique de l'Ouest et du Centre. CIRAD-CA G.E.C. - AMATROP. 66 p.

Menz K and Grist P, 1995. 'Shading Imperata with Rubber'. Imperata Project Paper, 1995/4, CRESS, ANU: Canberra.

Merlier $\mathrm{H}$ and Montegut J, 1982. Adventices tropicales: Flore aux stades plantules et adultes de 123 species africaines ou pantropicales. ORSTOM, CIRAD-GERDAT, ENSH. Montpellier, France. Paris. 490p.

RBI, 2005. Rubber and Its Cultivation. Rubber Board India (RBI), Ministry of Commerce and Industry. Government of India: Kottayam. 